\title{
Akar Historis Formalisasi Hukum Islam di Nusantara
}

\author{
Sarkowi, Agus Susilo
}

Departemen Pendidikan Sejarah, Sekolah Tinggi Keguruan dan Ilmu Pendidikan-Persatuan Guru Republik Indonesia Lubuk Linggau

Lubuk Linggau, Sumatera Selatan - Indonesia

*Alamat korespondensi: sarkowisulaiman@gmail.com

DOI: https://doi.org/10.14710/jscl.v5i1.21697

Diterima/Received: 10 Januari 2019; Direvisi/Revised: 20 Oktober 2019; Disetujui/Accepted: 11 Februari 2020

\begin{abstract}
This study was focused on the historical roots of Islamic law's formalization in Indonesia. It was started from the discourse of pros and cons on which took place since the Indonesian independence, to be exacted when nine committees of BPUPKI formulated the state principles. It was continued during the Liberal Democracy era of the Old Era, New Era until Reformation. The objective of this study was to construct the historical roots of Islamic law formalization using historical methods with the philosophical approach to the contextual analysis. The results of this study show that the historical roots were started from the success of the ulama and their role, until the establishment of Islamic empires, then Islamic law was legalized in the form of legislation by adopting legal books written by the scholars. There was stronglegitimacy of the role of ulama, as well as the Sultan's commitment to governing society through the judiciary and positions of qadhi, mufti and shaykh al-Islam which become the main pillars of the Islamic formalization practice in the sultanate government in Nusantara.
\end{abstract}

Keywords: Historical Roots; Formalization of Islamic Law; Nusantara.

\begin{abstract}
Abstrak
Kajian ini menganalisis akar historis formalisasi hukum Islam di Nusantara yang diawali dengan pro dan kontra terhadap wacana formalisasi hukum Islam di Indonesia, sejak menjelang kemerdekaan Republik Indonesia, tepatnya pada saat perumusan dasar negara oleh Panitia Sembilan Badan Penyelidik Usaha-usaha Persiapan Kemerdekaan Indonesia (BPUPKI), kemudian berlanjut pada masa Demokrasi Liberal era Orde Lama, Orde Baru, hingga era Reformasi. Penelitian ini bertujuan untuk melakukan konstruksi akar historis formalisasi hukum Islam di Nusantara. Metode sejarah dengan pendekatan falsafi model analisis kontekstual digunakan untuk menelaah dan menganalisis permasalahan tersebut. Hasil penelitian menunjukkan bahwa akar historis formalisasi hukum Islam di Nusantara berawal dari keberhasilan dakwah para ulama dan mubaligh, hingga pendirian kerajaan-kerajaan Islam di Nusantara, selanjutnya hukum Islam dilegislasi dalam bentuk perundang-undangan maupun dengan cara mengadopsi kitab hukum yang ditulis oleh para ulama. Penguatan legitimasi dan peran ulama, serta komitmen para sultan dalam sistem pemerintahan melalui lembaga peradilan dan jabatan qadhi, mufti, dan syaikh al-Islam menjadi penopang utama praktik formalisasi hukum Islam dalam pemerintahan kesultanankesultanan di Nusantara.
\end{abstract}

Kata Kunci: Akar Historis; Formalisasi Hukum Islam; Nusantara.

\section{Pendahuluan}

Seiring dengan perkembangan agama Islam di Nusantara, muncul kekuatan politik Islam secara konstitusional. Pelembagaan hukum Islam oleh negara di Nusantara berdasar pada bukti-bukti historis telah dilaksanakan sejak masa Kesultanan Samudra Pasai pada abad ke-14. Hal ini setidaknya dapat dibuktikan dengan munculnya Sultan Malik al-Shaleh, seorang sultan yang ahli dalam bidang fiqh mazhab as-Syafi'i. Dalam bidang pelaksanaan hukum atau peradilan, sultan dibantu oleh seorang 
qadhi (hakim) dan para ulama dari mancanegara (Sunanto, 2007: 136). Bahkan, ada yang berpendapat bahwa formalisasi hukum Islam oleh negara sudah ada pada masa Kesultanan Perlak yang berdiri pada 1 Muharram $225 \mathrm{H}$ atau 12 November 839 M (Arifin, 2005: xxxvi). Jika demikian, hal ini menunjukkan bahwa pelaksanaan atau formalisasi hukum Islam di Nusantara sudah berlangsung sejak kesultanan Islam pertama. Kemunculan Kesultanan Aceh Darussalam, Kesultanan Malaka dan beberapa kesultanan Islam di Pulau Jawa, Kalimantan, Sulawesi, dan Maluku merupakan kekuatan politik baru setelah masa kemunduran Kesultanan Samudra Pasai dan jatuhnya Malaka ke tangan Portugis pada 1511.

Meskipun formalisasi hukum Islam memiliki akar sejarah yang jelas, dalam perkembangan berikutnya kekuasaan politik di Bumi Nusantara jatuh ke tangan kolonial Barat, terutama politik imperialisme Belanda berikut produk hukum yang ditanamkannya, turut mereduksi memori masyarakat Indonesia terhadap formalisasi hukum Islam yang pernah ada sebelumnya. Bahkan keberadaan hukum Islam saat ini belum mendapat tempat secara proporsional di dalam kehidupan bernegara. Persoalan ini ditambah lagi dengan anggapan miring terhadap hukum pidana Islam yang terkesan kejam dan membutuhkan upaya reformasi. Bahkan ada yang menganggap perlunya reinterpretasi atas hukum perdata Islam, terlebih hukum pidana Islam yang dituding tidak sejalan dengan Hak Asasi Manusia (HAM) atau nilai-nilai kemanusiaan oleh kelompok yang berfaham sekular dan liberal. Bahkan Yusdani (2006) menyimpulkan tuntutan formalisasi syariat atau hukum Islam di berbagai negeri Islam termasuk Indonesia belum memiliki konsep yang jelas.

Selain itu, rumusan formalisasi hukum Islam oleh kelompok yang kontra dianggap kejam, incompatible, dan ketinggalan zaman, namun sebagian umat muslim yang lainnya menghendaki pemberlakuan kembali hukum Islam yang dianggap pernah diterapkan pada masa kesultanan Islam di Nusantara. Kelompok umat Islam yang menginginkan kembali hukum Islam ini, oleh Nashir (2013: 292-416) terdiri dari islamisasi jalur bawah dan islamisasi jalur atas. Sebagian kalangan masyarakat menilai, tidak tercapainya keadilan dan kepastian hukum akibat mengabaikan hukum- hukum Islam dalam pemerintahan. Bahkan terkadang hukuman yang dijatuhkan kepada pelaku kejahatan tidak sebanding dengan tindakan kejahatan yang dilakukannya, sehingga beberapa daerah mencoba melakukan legislasi hukum Islam dalam peraturan daerahnya, namun tetap saja pincang karena menjadi subordinat dari hukum negara yang lebih tinggi. Bahkan dari hasil penelitian Hidayat (2012) menemukan 56 anggota DPR RI memandang negatif terhadap pemberlakuan peraturan daerah syariah dengan anggapan bertentangan Pancasila dan UUD 1945. Meskipun demikian, dalam ranah hukum keluarga, sebagian hukum Islam sudah dikompilasi dan ditransformasikan menjadi hukum positif (Hikmatullah, 2017).

Wacana formalisasi hukum Islam secara menyeluruh dalam bingkai negara atau hukum positif di Indonesia hingga saat ini masih diperdebatkan antara pihak yang pro dan pihak yang kontra. Pihak yang pro berargumentasi bahwa pemberlakuan hukum Islam dalam bernegara merupakan bentuk pengamalan keyakinan beragama yang sudah mengakar kuat pada bangsa Indonesia dan amanah dari konstitusi, sementara pihak yang kontra berargumentasi bahwa pengamalan ajaran Islam sudah terakomodasi dalam hukum dan peraturan perundang-undangan yang berlaku, misalnya undang-undang perkawinan, peradilan agama, kompilasi hukum Islam, penyelenggraan ibadah haji, kompilasi hukum Islam, ekonomi syariah dan perda-perda syariah (Saidah, 2013).

Untuk menelaah kajian akar formalisasi hukum Islam di Nusantara, diketengahkan beberapa hasil kajian penelitian terdahulu yang dijadikan sebagai pembanding dalam menelisik dan menganalisis penelitian ini, antara lain: Hidayat (2012) menganjurkan pentingnya mempertahankan kesinambungan syariat Islam dalam kerangka konstitusional di Indonesia; Nashir (2013) menggambarkan gerakan Islam syariat sebagai bentuk pengulangan atau reproduksi ulang dari salafiyah ideologis yang sudah ada sejak masa lalu; Saidah (2013) mendudukkan peluang dan tantangan aktualisasikan hukum Islam di Indonesia; Yunus (2015) mendeskripsikan penerapan syariat Islam terhadap peraturan daerah dalam sistem hukum nasional 
Indonesia; Usman (2014) menelaah konsep pembinaan umat dan strategi pelaksanaan Islam di Aceh; Syamsuddin (2015) menggambarkan transformasi hukum Islam di Indonesia; Sirajuddin (2016) menjelaskan pergulatan politik hukum Islam di Indonesia; Kenedi (2017) mengungkapkan penerapan syariat Islam dalam lintasan sejarah dan hukum positif di Indonesia, dan menganalisis pengaruh teori recieptie Snouc Hurgronje terhadap hukum Islam di Indonesia. Penulis juga mengetengahkan laporan Ibnu Batutah (1992) dalam karya Rihlah-nya dan Hikayat Raja-Raja Pasai untuk mendapatkan penafsiran baru.

Berbeda dari kajian-kajian terdahulu di atas yang fokus pada pembahasan pengamalan dan prospek pelaksanaan hukum Islam dalam konteks Indonesia dengan kacamata perspektif hukum, kajian ini lebih khusus bertujuan untuk melakukan konstruksi asal-usul formalisasi hukum Islam di Nusantara. Oleh sebab itu, penelitian ini berusaha menyoroti bagaimana proses awal muncul formalisasi hukum Islam di Nusantara, peran ulama dalam formalisasi hukum Islam di Nusantara, dan praktik pelaksanaan hukum Islam yang dijalankan dalam kesultanan-kesultanan di Nusantara. Untuk menganalisis permasalahan tersebut, penulis menggunakan metode sejarah dengan pendekatan falsafi model analisis kontekstual untuk menggambarkan sosiohistoris pada zaman tersebut, sehingga kontribusi penelitian ini diharapkan sebagai kontribusi untuk menemukan latar belakang historis, politik, dan sosial keagamaan formalisasi hukum Islam yang dipandang sangat krusial dalam perjalanan sejarah bangsa.

\section{Metode}

Penelitian ini menggunakan metode historis dengan pendekatan falsafi, yaitu model pendekatan normatif yang didasarkan pada pemikiran hukum fikih, ulama, ilmuwan, dan tokoh tertentu. Data diperoleh melalui penelusuran dan penelaahan terhadap referensi, jurnal, catatan-catatan, dan sumber-sumber kepustakaan yang relevan. Menurut Gilbert (Abdurrahman, 2007: 53) metode penelitian sejarah adalah seperangkat aturan dan prinsip sistematis untuk mengumpulkan sumber-sumber sejarah secara efektif, menilainya secara kritis, dan mengajukan sintesis dari hasil-hasil yang dicapai dalam bentuk tertulis. Arif (2011: 30) menyebutkan metode sejarah berhubungan dengan bagaimana mengetahui sejarah. Selanjutnya Kartodirjo (1993: 2) menjelaskan bahwa metode sejarah merupakan bagian pokok dalam ilmu sejarah tidak hanya menekankan menceritakan kejadian tetapi bermaksud menerangkan kejadian itu dengan mengkaji sebab-sebabnya, kondisi lingkungan, konteks sosiokultural, serta analisis tentang faktorfaktor kausal, kondisional, kontekstual, serta unsurunsur yang merupakan komponen dan eksponen dari proses sejarah yang dikaji.

Pelaksanaan metode sejarah menurut Notosusanto melalui tahapan heuristik, kritik sumber, interpretasi dan penyajian atau historiografi (Sulasman, 2014: 75). Oleh sebab itu, metode sejarah tidak sekadar menceritakan suatu peristiwa secara deskriptif, melainkan untuk mengetahui secara utuh dengan sudut pandang dan prosedur yang telah ditetapkan oleh ilmu sejarah. Oleh karena itu, penelitian ini berupaya menggambarkan dan mengeksplanasi akar historis formalisasi hukum Islam di Nusantara dengan teknik kritik analitik dengan pendekatan falsafi yang bersifat contextual analisys atas sumbersumber sejarah yang berasal dari jurnal, disertasi, buku, prosiding, dan majalah yang relevan untuk mendapatkan kebaruan dari hasil kajian ini.

\section{Proses Awal Penerapan Hukum Islam di Nusantara}

Sejarah perkembangan hukum Islam dan formalisasi hukum Islam di Nusantara tidak dapat dipisahkan dari sejarah masuknya Islam ke Nusantara itu sendiri. Pembahasan hukum Islam sama tuanya dengan Islam sebagai sebuah agama, namun bicara tentang formalisasi hukum Islam di Nusantara tidaklah sama tuanya dengan awal keberadaan Islam. Begitu juga ketika membicarakan formalisasi hukum Islam dalam pemerintahan tidak dapat dipisahkan dari ajaran Islam itu sendiri. Menurut Joseph Sacht, tidak mungkin dapat mempelajari Islam tanpa mempelajari hukum Islam. Ini menunjukkan bahwa hukum Islam merupakan bagian dari institusi agama yang tidak dimiliki oleh agama lain (Nuruddin dan Tarigan, 2006: 2). Sementara lembaga pengadilan merupakan peranti keras yang 
konkret dan terlembaga dalam pelaksanaan hukum-hukum Islam (Mukhlas, 2011: 3). Tentunya keberadaan peradilan merupakan salah satu pilar pelaksanaan hukum Islam dalam suatu pemerintahan, sebab dalam Islam hukum berhubungan dengan perbuatan setiap mukallaf yang wajib terikat dengan hukum Islam (Hikmatullah, 2017).

Islam pertama kali masuk ke Indonesia, meskipun masih dalam perdebatan, terjadi pada abad pertama hijriah atau abad VII masehi (Rusdi, 2011:39; Ali, 2011: 209; Hamka, 1981: 35). Pada masa awal, hukum Islam belum dapat disebut sebagai pranata dalam suatu sistem pemerintahan, karena pada saat itu masih dilaksanakan secara individu atas dasar keimanan dan belum ada badan legislasi atau pemberlakuan hukum Islam dalam pemerintahan. Hukum Islam baru dalam taraf pengenalan dan proses adaptasi dengan budaya setempat yang dilakukan oleh para ulama dan mubaligh sekaligus sebagai upaya penyebaran Islam atau dakwah islamiyah. Tahap ini hukum Islam baru diperkenalkan kepada orang-orang atau komunitas yang telah menerima Islam. Meskipun tahap ini hanya berupa pengajaran dan pembinaan, namun sangat menentukan perkembangan dalam penerimaan hukum Islam pada tahap berikutnya, saat Islam menjelma menjadi kekuatan politik. Tahap ini merupakan proses kristalisasi normanorma Islam di tengah-tengah masyarakat secara bertahap. Pada masa awal ini secara perlahan-lahan Islam diterima oleh masyarakat dan menggeser ajaran Hindu-Buddha dan adat istiadat yang dihasilkannya. Ajaran Islam secara berangsurangsur diterapkan dan dilaksanakan dalam kehidupan sehari-hari, baik dibidang ibadah mahdhah (habl min Allah), muamalah dan munakahat (Mukhlas, 2011: 119).

Dalam proses islamisasi tahap awal ini dilakukan oleh para ulama, mubaligh dan pedagang, khususnya ulama dan pedagang asal dari Timur Tengah. Pengenalan ajaran Islam kadang ditempuh melalui saluran perdagangan dan perkawinan. Pada tahapan ini meskipun dalam skala kecil hukum Islam sudah mulai diperkenalkan, hal ini dapat dilihat dari kenyataan bahwa jika seorang mubaligh hendak menikahi seorang wanita pribumi, maka wanita tersebut harus diislamkan terlebih dahulu dan pernikahannya dilangsungkan menurut ketentuan hukum Islam. Keluarga yang tumbuh dari perkawinan ini mengatur hubungan antaranggotaanggota keluarganya dengan kaidah-kaidah hukum Islam atau budaya lama yang telah disesuaikan dengan nilai-nilai Islam. Kalau salah seorang anggota keluarga itu meninggal dunia, harta peninggalannya dibagi menurut hukum kewarisan Islam (Ali, 2011: 233).

Pada fase ini tentunya hukum-hukum Islam sudah diperkenalkan kepada seluruh anggota keluarga maupun masyarakat yang telah menerima Islam. Setiap individu muslim ditanamkan keterikatan terhadap hukum-hukum Islam yang menyangkut urusan ibadah, akhlak maupun muamalah, namun pada fase ini diduga kuat juga telah diperkenalkan hukum-hukum yang berkaitan dengan uqubat (hukum berkaitan dengan pidana, sanksi dan pelanggaran) yang meliputi hukum hudud, jinayat, takzir dan mukhalafat sebagai pemahaman tsaqofah (pengetahuan) Islam. Karena perkara ini berhubungan dengan persoalan kehidupan sehari-hari, walaupun baru dalam batasan yang bersifat normatif. Meskipun secara yuridis, norma dan regulasi yang mengikat untuk melaksanakan hukum Islam dalam penyelesaian perkara belum ada, namun secara de facto praktik penyelesaian suatu perkara berdasar peraturan Islam sudah dirasakan oleh masyarakat muslim. Pada masa ini norma hukum Islam dan budaya masyarakat telah mulai menyatu sesuai kaidah Islam, sehingga kemudian menjadi falsafah hidup di tengah masyarakat (Sirajuddin, 2016).

Melalui proses islamisasi dan kulturisasi hukum Islam terus berkembang sejalan dengan semakin meluasnya pengaruh agama Islam di Nusantara (Sarkowi \& Akip, 2019). Hukum Islam pun menjadi bagian dari hukum adat yang berkembang di Nusantara berkat akulturasi dan asimilasi budaya Islam (dalam hal ini hukum Islam) dan budaya lokal. Islam mulai dianut oleh komunitas dalam suatu masyarakat yang teratur namun belum sampai pada bentuk masyarakat yang mempunyai pemerintahan Islam. Ketika itu pula hukum Islam dilaksanakan oleh kelompok masyarakat tersebut. Jika terjadi persengketaan biasanya dari pihak yang bersengketa itu mengangkat seorang muhakkam (pemutus perkara) secara tahkim dari kalangan ulama atau 
mullah di antara mereka yang dianggap memiliki kemampuan dalam hukum Islam, dan ini merupakan bentuk awal formalisasi hukum Islam secara sederhana yang pertama-tama diberlakukan di Nusantara yang biasanya dikenal dengan fase tahkim (Noeh, 1986: 2).

Hukum Islam pada saat itu masih tidak tertulis seperti halnya hukum adat. Artinya, tidak tertulis dalam bentuk perundang-undangan. Hukum Islam yang berlaku di peradilan sederhana pada saat itu adalah hukum fikih hasil ijtihad para ulama yang dilakukan secara patuh oleh masyarakat atau komunitas Islam karena kesadaran dan keyakinan mereka bahwa hukum Islam adalah hukum yang benar (Ali, 2011: 211). Sebab setiap muslim yang taat akan mengikuti hukum-hukum yang berpangkal dari sumber-sumber ajaran Islam itu sendiri yang telah ditanamkan oleh para ulama sebagai orang yang lebih memahami kandungan ajaran Islam. Pada masa ini peran ulama dari Timur Tengah sangat berpengaruh dalam memperkenalkan hukum Islam dan kaderisasi tunas ulama pribumi. Pengaruh mereka bahkan berlanjut hingga masa penyebaran agama Islam di Jawa. Sebab para Wali Songo pada masa awal adalah para ulama dan ahli tata negara dari Timur Tengah yang diutus oleh Sultan Muhammad I dari kekhalifahan Turki Usmani (Abdullah, 2015: 75-88).

Karakter masyarakat Nusantara, umumnya Pulau Sumatra sangat patuh terhadap pemimpinpemimpin adat dan tokoh-tokoh agama atau spiritual. Setelah mereka menerima Islam, para tokoh atau ulama menjadi pemutus dalam suatu perkara. Agak berbeda dari Pulau Jawa pada awalnya kecenderungan dan ketaatan masyarakat secara umum sangat patuh terhadap pemimpin politik struktural pemerintah. Hal ini menjadi salah satu alasan mengapa Wali Songo mendukung dan menginisiasi Raden Fatah untuk membentuk pemerintahan kerajaan Islam di Jawa, karena Raden Fatah dianggap sebagai pewaris Kerajaaan Majapahit yang sah, sehingga di Jawa peran ulama yang tergabung dalam Wali Songo ini berhasil mendirikan Kerajaaan Islam Demak Bintoro pada Senin Kliwon, malam Selasa Legi, 11 malam 12 Rabi'ul Awwal tahun $860 \mathrm{H} / 1404 \mathrm{C} / 1482 \mathrm{M}$ dan mengangkat Sultan Fattah sebagai raja Islam pertama di Jawa (Abdullah, 2015: 13). Dalam pandangan ulama mendirikan pemerintahan dan peradilan untuk menegakkan hukum Islam adalah fardhu kifayah (Noeh, 1986:2).

Masifnya dakwah yang dilakukan oleh para ulama dan mubaligh serta semakin meluasnya penerimaan Islam di tengah masyarakat, maka berdirilah beberapa kekuasaan Islam di Nusantara. Institusi politik pemerintahan Islam pertama berdiri di Nusantara adalah Kesultanan Perlak (Peureulak), berdiri pada 1 Muharram $225 \mathrm{H}$ atau 12 November 839 M (Uwik, 2011: 70). Sementara itu, menurut Daliman (2012: 99) Kesultanan Perlak berdiri pada abad ke-12. Menurut spekulasi Yatim (2016:194) cikal bakal kekuasaan Islam masa ini tenggelam dalam hegemoni Sriwijaya. Menurut Usman (2014) kerajaan ini telah melaksanakan hukum Islam dalam pemerintahannya. Sultan pertamanya bernama Alaiddin Sayyid Maulana Abdul Aziz Syah, meskipun belum banyak keterangan mengenai pelaksanaan hukum Islam dalam pemerintahan ini, kecuali keterangan dari Marcopollo. Namun sebagai institusi yang mendelakrasikan sebagai kerajaan Islam, bisa dipastikan bahwa Kesultanan Perlak telah menerapkan hukum Islam di lingkungan pemerintahannya. Pergeseran praktik akulturasi ke legalisasi hukum ini semakin jelas keterangannya setelah berdiri Kesultanan Samudra Pasai.

Samudra Pasai terletak di Aceh Utara didirikan oleh Sultan Malik as-Saleh pada 1267 (Achmad, 2016: 39-40). Sejak berdirinya Samudra Pasai dapat dipandang sebagai genealogi awal pemberlakuan hukum Islam sebagai hukum negara di Nusantara. Ibnu Batutah penjelajah muslim dari Maroko mempunyai catatan unik yang berkaitan dengan pemberlakuan hukum Islam dalam sistem peradilan pada masa pemerintahan Malik al-Zahir di Samudera Pasai. Dalam catatannya, Ibnu Batutah sangat mengagumi kemampuan sang sultan dalam berdiskusi tentang berbagai masalah Islam dan ilmu hukum Islam. Pada masa ini hukum yang digunakan sebagai rujukan dalam peradilan untuk memutuskan perkara hukum masih terbatas pada hukum fikih yang dikodifikasikan oleh ulamaulama Timur Tengah dari karya ulama-ulama mazhab, khusus fikih mazhab Syafi'i. Sebab menurut catatan sejarah, Kesultanan Samudra Pasai mengadopsi hukum Islam mazhab fikih Syafi'i, selanjutnya diperkenalkan dan menyebar ke berbagai kerajaan Islam lainnya di tanah air pada masa berikutnya (Ali dalam Surjaman, 1991: 69). 
Bahkan, menurut Hill (1963: 8) sejak berdiri, Samudra Pasai berkembang menjadi pusat kekuatan politik Islam sekaligus basis islamisasi. Dari keterangan tersebut menegaskan bahwa Samudra Pasai tidak hanya sebagai pemerintahan masa awal melakukan formalisasi hukum Islam di Nusantara, namun lebih dari itu tersirat bahwa Samudra Pasai sebagai pusat islamisasi di Nusantara. Hal ini dapat dibuktikan dari para ulama mancanegara yang akan berdakwah di Pulau Jawa dan daerah lain biasanya terlebih dahulu singgah di Samudra Pasai.

Kemunculan kekuatan politik Islam di Nusantara menandakan adanya pergeseran dalam pelaksanaan hukum Islam dari pengamalan oleh individu dan proses akulturasi dengan tradisi lama menuju legislasi hukum oleh pemegang otoritas kekuasaan di berbagai kerajaan Islam di Nusantara. Kalangan elite kerajaan menggunakan kekuatan, birokrasi, dan hegemoni kultur politik dalam proses internalisasi norma Islam atau hukum Islam (Reids, 1993: 84-107). Peran ulama adalah sebagai peranti pelaksana dan legitimasi kekuasaan yang menerapkan peraturan Islam. Pergeseran ini menandai dimulainya formalisasi hukum Islam dalam sistem pemerintahan saat itu.

\section{Ulama dan Formalisasi Hukum Islam di Nusantara}

Sejak awal penyebaran Islam di Nusantara tidak bisa dipisahkan dari peran para ulama atau pendakwah yang diutus langsung dari pusat pemerintahan Islam di Madinah, Damaskus, Baghdad, Istambul atau yang datang atas inisiatif sendirinya. Menurut sumber Hikayat Raja-Raja Pasai, islamisasi di Samudera Pasai dilakukan oleh seorang ulama asal Timur Tengah, Syekh Ismail (Hill, 1960: 56-57). Sumber ini juga banyak memberikan gambaran tentang pelaksanaan hukum Islam di Samudra Pasai, termasuk juga peran para ulama. Pengaruh para ulama ini kemudian berhasil mewarnai kehidupan masyarakat dan institusi politik di Nusantara. Setelah Islam bekembang dan menjelma menjadi sebuah kekuatan politik, hukum-hukum Islam diterapkan dalam sistem pemerintahan dengan menjadikannya sebagai hukum negara menggantikan hukum adat di berbagai daerah
Nusantara (Maman, 2009: 101). Melihat adanya peran jaringan ulama dari Timur Tengah pada masa awal ini diperkirakan para ulama telah berhasil melakukan kaderisasi dan mencetak ulama-ulama asli Nusantara. Hal ini dibuktikan dengan kemunculan ulama-ulama pribumi yang berpengaruh besar dalam islamisasi dan perpolitikan di Nusantara pada masa berikutnya.

Pelaksanaan hukum Islam membutuhkan lembaga peradilan (al-qadha) dan qadhi (hakim) yang dapat memberi dan menjamin keadilan serta adanya ketegasan hukum terhadap semua lapisan masyarakat. Sementara itu, ulama adalah orang yang dipandang paling memahami konsep dan pelaksanaan hukum dalam Islam, sehingga ulama dapat dianggap sesuatu yang tidak terpisahkan dalam pemberlakuan hukum Islam. Karena melalui ilmu para ulama diharapkan keadilan Islam melalui sistem peradilan dapat dirasakan di tengah kehidupan masyarakat, sehingga akan terwujud suatu kehidupan masyarakat yang damai dan rukun. Terkait dengan kelahiran ulama-ulama Melayu di Nusantara, menurut Azra (1994) karena jaringan ulama-ulama Timur Tengah sehingga menjadi sarana bagi kemunculan ulama-ulama Nusantara.

Sejak berdiri kekuatan politik Islam di Nusantara, ulama menjadi bagian penting dalam legitimasi kekuasaan di tengah masyarakat yang telah beralih menjadi muslim, sehingga setiap kesultanan biasanya mengangkat qadhi, mufti hingga syaikh al-Islam bagi ulama yang berpengaruh besar. Mereka tampil di tengahtengah masyarakat dalam menyelesaikan berbagai persoalan hukum Islam. Sebagaimana jabatan hakim dalam tradisi Islam sejak masa Nabi Muhammad saw., Khulafa ar-Rasyidin dan para khalifah setelahnya di negeri Islam, para hakim disebut dengan istilah qadhi. Dalam penerapan hukum Islam idealnya haruslah totalitas, bukan mengambil jalan tengah seperti yang dianjurkan Syamsuddin (2015).

Pengaruh ulama juga dapat disaksikan secara kultural mengkristal ke sendi-sendi kehidupan masyarakat. Hal ini dapat dibuktikan dengan slogan-slogan yang masih berkembang hingga saat ini. Menurut Kenedi (2017) Minangkabau adalah salah satu daerah yang menerapkan hukum Islam pada masa lalu, hal ini dapat dibuktikan dengan 
eksistensi postulat yang berbunyi "adat basandi syarak, syarak basandi kitabullah" (adat bersendi hukum Islam, hukum Islam bersendi kitabullah). Dari slogan tersebut tersirat bahwa kehidupan sosial masyarakat Minangkabau memedomani hukum Islam. Hal ini juga diperkuat dengan slogan lain disebutkan "adat dan syarak sanda-menyanda, syarak mengato adat memakai" (adat dan syarak saling menopang, syarak menyatakan adat memakaikan atau menjalankan). Hal ini menunjukkan adat dan hukum Islam saling menopang; selama adat bersesuaian dengan hukum Islam maka adat dilaksanakan atau tumbuh dari hukum Islam yang sudah mengakar dari kehidupan masyarakat. Akulturasi adat dengan hukum Islam yang serupa banyak juga dijumpai pada masyarakat adat Riau, Jambi, Palembang, Bengkulu, Lampung, dan berbagai daerah lain di Nusantara (Departemen Agama RI, 1985: 5).

Dalam perkembangan Islam di Nusantara, Sultan Muhammad I dari kekhalifahan Turki Usmani pernah mengutus para ulama untuk melakukan penyebaran Islam di Pulau Jawa, kemudian dikenal dengan sebutan Wali Songo. Ulama tersebut adalah Maulana Malik Ibrahim, ahli tata pemerintahan dari Turki, Maulana Ishaq dari Samarqand, yang dikenal dengan nama Syaikh Awwalul Islam, Maulana Jumadil Kubro dari Mesir, Maulana Muhammad al-Maghribi dari Maroko, Maulana Malik Israil dari Turki, Mualana Hasanuddin, Maulana Aliyuddin dari Palestina dan Syekh Subakir dari Persia. Mereka pada umumnya singgah di Samudra Pasai sebelum melanjutkan ke Jawa, karena pada saat itu Samudra Pasai telah menjadi kekuatan politik Islam. Bahkan Sultan Samudra Pasai, Sultan Zainal Abidin Bahiyan Syah (1421-1436 M) mengantar langsung Maulana Malik Ibrahim dan Maulana Ishaq ke Tanah Jawa (Maman, 2009:101).

Masifnya gerakan dan aktivitas dakwah para ulama yang terus menerus, maka terbentuklah berbagai institusi politik atau kesultanan Islam di Nusantara yang menjadi pintu akselerasi islamisasi dan cikal bakal formalisasi hukum Islam di Nusantara. Di Sumatra, Kesultanan Perlak berdiri pada 1 Muharram $225 \mathrm{H}$ atau 12 November $839 \mathrm{M}$, (Arifin, 2005: xxxvi) yang dipandang sebagai kerajaan Islam pertama di Nusantara (Usman, 2014). Kemudian disusul Kesultanan Samudra Pasai dan yang lainnya. Pengaruh ulama yang kuat dalam pendirian dan pemberlakuan hukum Islam di Nusantara dapat dibuktikan dari inisiasi ulama yang tergabung dalam Wali Songo dalam pendirian Kesultanan Demak Bintoro. Hal ini menunjukkan pengaruh ulama di Pulau Jawa berlangsung sejak awal pendirian kerajaan Islam pertama, bahkan Cirebon dan Banten didirikan oleh Sunan Gunung Jati, salah satu anggota Wali Songo. Formalisasi hukum Islam dalam institusi pemerintahan sudah tentu diawali proses akulturasi dengan adat istiadat dalam kehidupan masyarakat melalui proses dakwah yang telah dilakukan oleh para ulama. Kemudian setelah berdiri kesultanan Islam dilakukan proses legislasi dan formalisasi hukum oleh lembaga pemeritah. Secara struktural pihak penguasa menggunakan birokrasi dan hegemoni politik dalam melakukan proses internalisasi hukum-hukum Islam kepada rakyat (Reids, 1993: 84-107).

Konsepsi hukum Islam dalam sistem pemerintahan merujuk kepada sumber hukumhukum Islam yang terdiri dari Alquran, hadis, ijma sahabat dan qiyas. Akan tetapi, secara khusus konsepsi hukum Islam yang dijalankan pada kesultanan-kesultanan Islam di Nusantara tidak luput dari perjuangan dan peran para ulama, baik dalam tataran konseptual maupun pelaksanaannya. Formalisasi hukum Islam mengacu pada kitabkitab fikih yang ditulis oleh para ulama. Pada masa awal, meskipun karya ulama belum dapat dikatakan sebagai qanun atau perundang-undangan, namun beberapa buku karya ulama dijadikan rujukan dalam kehidupan bernegara dan penetapan hukum di beberapa kerajaan Islam di Nusantara, sehingga menjadi sumber penting sekaligus sebagai bukti atas penerapan hukum Islam dalam sistem peradilan dan pemerintahan di kesultanankesultanan Islam di Nusantara. Beberapa penelitian dijelaskan bahwa dalam buku-buku hukum tersebut dimuat pula tentang hukum pidana Islam.

Kuatnya pengaruh dan legitimasi ulama menjadi salah satu faktor utama kesultanankesultanan Islam di Nusantara mengadopsi undang-undang yang bersumber dari Islam dalam pemerintahannya. Di antara undang-undang kesultanan Islam di bumi Nusantara yang paling banyak disoroti adalah undang-undang yang terdapat pada Kesultanan Aceh Darussalam bernama Kitab Adat Meukuta Alam yang diadopsi 
dari hukum-hukum pidana dan perdata Islam. Undang-undang ini ditulis dalam huruf Arab Melayu (huruf Jawi) dan dijadikan undang-undang kerajaan (Usman, 2014). Undang-undang ini diberlakukan sejak masa Sultan Iskandar Muda, sementara ulama yang berpengaruh mendampingi sultan sebagai mufti pada masa itu adalah Syamsuddin Sumatrani, kemudian dilanjutkan oleh Nuruddin al-Raniri pada masa Sultan Iskandar Sani dan Sultanah Shafiyyah al-Din. Hal ini menandakan bahwa pada masa itu sudah dikenal sistem pemerintahan yang berdasar pada hukum yang terkodifikasi dan ulama dipercaya sebagai qadhi (hakim) sekaligus mengontrol pelaksanaan hukum Islam dalam pemerintahan.

Kemunculan undang-undang hukum Islam dan kitab hukum yang diadopsi oleh kesultanankesultanan Islam di Nusantara merupakan pengaruh dari kitab-kitab fikih yang disusun oleh beberapa ulama ahli hukum Islam di Nusantara. Nuruddin al-Raniri menulis buku hukum Islam berjudul Sirat al-Mustaqim pada 1628. Beliau disebut sebagai tokoh Islam abad ke-17 yang banyak melahirkan buku. Kitab Sirat al-Mustaqim ini menjadi dokumen hukum pertama yang disebar ke seluruh Nusantara. Bahkan buku ini yang disyarah oleh ulama besar Syaikh Arsyad al-Banjari menjadi buku Sabil al-Muhtadin li Tsaqah fi Amr al-Din sebagai pedoman dalam penyelesaian masalah hukum di Kesultanan Banjar (Sirajuddin, 2016). Selain buku di atas, karya-karya fiqih alRaniri lainnya berjudul Jawahir al- 'Ulum fi KasyfalMa'lum, Kaifiyat al-Shalat dan Tanbih al-'Awm fi Tahqiq al-Kalam fi al-Nawafil juga cukup berpengaruh terhadap perkembangan dan formalisasi hukum Islam di Nusantara (Nuruddin dan Tarigan, 2006: 4). Syaikh Nuruddin al-Raniri dianggap ulama pertama di Nusantara yang menulis buku pegangan standar mengenai kewajiban agama atau pengamalan hukum fikih secara mendasar bagi banyak orang di Nusantara pada saat itu, bahkan masih digunakan di beberapa daerah hingga saat ini (Azra, 1994: 186). Menurut Hasymi (1992: 46-52), kitab Masa'il al Muhtadi dan Sirat al Mustaqim adalah kitab Jawi yang paling populer di Asia Tenggara.

Di Aceh juga muncul ulama ternama, Abdul Rauf al-Sinkli atau Abdul Rauf Singkel. Beliau termasuk mujtahid di tanah Nusantara yang menulis karya fikih yang cukup dikenal luas. Karyanya berjudul Mir'at al-Thullab fi Tasyi alMa'rifah al-Ahkam al-Syar'iyah li al-Malik alWahhab ditulis atas permintaan Sultan Aceh, Sayyidat al-Din dan diselesaikan pada 1074 H/1633M. Menurut Azra (1994: 200) tampaknya buku ini ditulis dalam suasana psikologis yang mendua. Penerimaan al-Sinkli terhadap kepemimpinan wanita di Aceh dipandang bahwa ia telah mengompromikan integritas intelektualnya dengan realitas yang ada. Walaupun demikian, setidaknya hal ini menunjukkan keberadaan ulama merupakan penentu dan dianggap sebagai ujung tombak dalam pemberlakuan hukum-hukum Islam di Aceh pada saat itu.

Di Kalimantan muncul ulama yang sangat berpengaruh dalam islamisasi dan memperjuangkan formalisasi hukum-hukum Islam di tanah Banjar, yakni Syaikh Muhammad Arsyad al-Banjari (1122-1227 H/1710-1812). Di antara buku hukum di bidang fikih yang paling masyur berjudul Sabil al-Muhtadin. Al-Banjari menjadikan doktrin hukum Islam sebagai acuan dalam pengadilan kriminal, memprakarsai pendirian pengadilan Islam dan jabatan mufti dalam pemerintahan dan kehidupan sosial di Kesultanan Banjar (Azra, 1994: 252-254). Ini artinya Sultan Banjar melakukan legalisasi hukum Islam melalui buku Sabil al-Muhtadin yang ditulis oleh ulama ternama, Syekh Arsyad Banjari.

Begitu juga dengan formalisasi dan pelaksanaan hukum Islam di Tanah Jawa, tidak lepas dari pengaruh ulama. Misalnya jabatan qadhi pada pemerintahan Demak dipegang oleh Sunan Kalijaga seorang ulama anggota Wali Songo generasi akhir. Sementara di Kesultanan Banten peran ulama sangat diutamakan dalam pelaksanaan hukum Islam dalam pemerintahan, bahkan pada masa-masa awal qadhi hakim tertinggi dijabat ulama dari Mekkah, baru kemudian dipercayakan kepada ulama setempat (Sunanto, 2007:154). Di Cirebon misalnya, ada Papakem Cirebon sebagai kumpulan buku hukum yang mengatur perilaku hukum masyarakat Cirebon ketika itu. Di dalamnya terdapat buku hukum yang berjudul Jaya Lengkara, Hukum Raja Niscaya, Undang-undang Matoram, Kontra menawa dan Adilullah. Sekalipun dikenal sebagai hukum Jawa Kuno, akan tetapi dari segi isinya dipengaruhi oleh nilai-nilai 
hukum Islam (Rusdi, 2011: 48). Dengan melihat posisi ulama dalam pemerintahan tersebut, para ulama dianggap sebagai garda terdepan dalam pelaksanaan hukum Islam dalam pemerintahan kesultanan Islam di Nusantara.

\section{Praktik Penerapan Hukum Islam pada Masa Kesultanan di Nusantara}

Setelah Perlak dan Samudra Pasai susul menyusul berdirilah berbagai kerajaan Islam di Nusantara. Kerajaan bercorak Islam ini dikenal dengan istilah kesultanan dan rajanya disebut sultan. Kemunculan kesultanan ini juga diikuti dengan pergeseran hukum yang diberlakukan pihak kerajaan, sebelumnya mengadopsi hukum adat atau hukum kerajaan yang mendapat pengaruh tradisi lokal dan Hindu-Buddha kemudian secara bertahap menuju pemberlakuan hukum Islam atau hukum adat yang telah berakulturasi dengan hukum Islam, sehingga napas hukumnya tetap bercorak Islam atau bermuatan nilai-nilai Islam. Menurut Mukhlas (2011: 121) sesuai dengan teori receptio in complexu yang digagas Salomon Keyzer (1823-1868) menggariskan bahwa bangsa Indonesia berlaku hukum menurut agamanya. Oleh karena komunitas muslim tumbuh menjadi penduduk mayoritas, maka ajaran agama Islam menjadi pedoman dalam kehidupannya, temasuk dalam masalah hukum.

Praktik birokrasi dalam formalisasi hukum Islam dapat diketahui dari legislasi hukum Islam yang dilakukan oleh kesultanan-kesultanan Islam di Nusantara. Praktik penerapan hukum Islam meniscayakan adanya lembaga peradilan. Seorang pengembara Arab yang termasyur, Ibnu Batutah (1992: 619) dalam karya Rihlah-nya yang fenomenal melaporkan bahwa ketika menerima berita kedatangan Ibnu Batutah dari syahbandar, Amir Daulasah diperintahkan untuk menemuinya bersama al-qadhi as-syarif (hakim yang mulia), Amir Sayyid as-Syairazi dan Taj ad-Din al-Isbahani dan para fukaha (ahli fikih). Sebagaimana tradisi dalam kekuasaan Islam sejak masa Nabi Muhammad saw. hingga masa kekhalifahan berikutnya, gelar qadhi adalah sebutan untuk hakim yang bertugas menyelesaikan perkara di lembaga peradilan negara berdasar hukum Islam. Pendapat yang menyatakan syariat Islam atau hukum Islam tidak pernah diterapkan sebagai hukum negara sepanjang sejarah di Indonesia pada masa lalu, bertolak belakang dengan laporan Ibnu Batutah ini.

Perihal di atas membuktikan bahwa Samudra Pasai memberlakukan hukum Islam sebagai hukum negara. Menurut Israeli (1989: 181) Ibnu Batutah juga mengagumi kehebatan Sultan al-Malik al-Zahir dalam pemahaman hukum Islam, sehingga tidak dapat dipandang sebagai figur raja semata namun juga seorang ahli fikih mazhab Syafi'i yang banyak dianut masyarakat Pasai. Hal senada juga disampaikan Marcopollo ketika singgah di Peureula (Perlak) sebelum kemunculan Kesultanan Samudra Pasai. Sultan telah menyatukan adat istiadat dengan ajaran Islam. Pascakemunduran Samudra Pasai, Kesultanan Aceh muncul sebagai kekuatan politik, ekonomi, dan pusat penyebaran agama Islam. Salah satu faktor pendukungnya adalah letak Aceh yang sangat strategis di pintu masuk wilayah Nusantara lainnya. Dalam praktik positivasi atau formalisasi hukum Islam, Aceh sepertinya mempunyai pengaruh besar kepada praktik hukum Islam di kerajaan-kerajaan Islam Indonesia lainnya (Harjono, 1995: 121; Azra 1999: 69-71).

Pelaksanaan hukum Islam pada kesultanan di Nusantara ditandai dengan kemunculan berbagai lembaga pengadilan Islam. Misalnya, di Jawa ada Peradilan Serambi, Mahkamah Syar'iyyah di Sumatra, Kerapatan Qadhi di Banjar dan Pontianak. Peradilan ini selain menyelesaikan kasus-kasus perdata juga menyelesaikan kasuskasus pidana (Sirajuddin, 2016). Oleh sebab itu, Triyanta (2002) berkesimpulan hukum Islam yang diberlakukan pada masa lalu adalah hukum positif. Dengan demikian, perangkat utama dalam penerapan hukum Islam terdiri dari qadhi sebagai hakim dari kalangan ulama dan lembaga peradilan sebagai institusi pemerintah dalam penyelesaian perkara-perkara hukum.

Dalam praktik formalisasi hukum Islam di Nusantara, Kesultanan Aceh Darussalam termasuk pemerintahan yang cukup murni dalam pelaksanaannya, tanpa tebang pilih, baik terhadap rakyat biasa maupun terhadap bangsawan dan keluarga sultan. Hal ini bisa buktikan saat masa Sultan Iskandar Muda berkuasa, ia pernah menjatuhkan hukuman rajam terhadap puteranya sendiri yang bernama Meurah Pupok yang terbukti berzina dengan seorang isteri perwira. Pada masa 
Sultan Alauddin Syah dan Iskandar Muda hukum Islam tidak hanya mengatur perdata dan pidana saja, tetapi hukuman takzir terhadap pelanggaran ibadah, seperti shalat lima waktu sehari semalam dan ibadah puasa. Dalam bidang ekonomi misalnya, Sultan Iskandar Muda mengeluarkan kebijakan atau melegislasi hukum pengharaman riba dan dirham dijadikan sebagai mata uang Aceh. Kesultanan Aceh Darussalam ini sudah dilengkapi dengan Undang-undang Dasar yang berlandaskan Islam dengan nama Kitab Adat Meukuta Alam (Sunanto dalam Sarkowi, 2015: 116; Rusdi, 2011: 45-46). Dalam pelaksanaan hukum Islam, qadhi memiliki wewenang memutuskan perkara di pengadilan. Keterangan ini menunjukkan bahwa pelaksanaan hukum Islam di Kesultanan Aceh Darussalam dilaksanakan secara murni dan menyeluruh, tidak terbatas pada pengaturan hubungan antarmasyarakatnya dalam perkara muamalat dan tindak pidana, tetapi juga berkaitan dengan ibadah salat dan puasa pun diatur secara ketat. Dari keterangan dan penjelasan tersebut maka wajar AC Milner mengatakan bahwa Aceh merupakan kerajaan Islam di Nusantara yang paling ketat dalam melaksanakan hukum Islam pada peradilan sebagai hukum negara pada abad ke-17 (Rusdi, 2011: 45).

Menurut Beaulieu (dalam Lombard, 2014: 118) peradilan pelaksanaan hukum Islam pada masa pemerintahan Sultan Iskandar Muda terdiri dari pengadilan perdata, pidana, agama, dan niaga. Sepertinya Beaulieu kurang memahami konsep hukum dalam Islam, sehingga ia memisahkan konsep hukum perdata, pidana, dan niaga dengan agama, padahal ketiga hukum tersebut adalah bagian dari hukum agama atau bisa juga peradilan agama yang dimaksud adalah perkara yang berkaitan ibadah. Namun Beaulieu sepertinya juga gagal dalam menggambarkan Sultan Iskandar Muda sebagai seorang yang kejam dengan menyiksa banyak orang termasuk putranya sendiri, sebagai seorang gangguan saraf dan berwatak tidak stabil (Lombard, 2014: 240-241). Tuduhan ini menunjukkan ketidakpahamannya terhadap hukuman pidana bagi orang yang melakukan kejahatan dalam Islam atau ada unsur kesengajaan untuk mendistorsikan fakta sejarah.

Dalam bidang perdagangan dan perekonomian tidak hanya Aceh, pada umumnya di berbagai kesultanan Islam di Nusantara berlaku sistem kelembagaan kemitraan dagang (syarikah mufawwadhah) dan sistem commenda atau kepemilikan modal (Arab: qirad, mudharabah) (Rusdi, 2011: 40). Hukum tersebut adalah bagian hukum perekonomian Islam. Ini menunjukkan bahwa pada masa itu telah diterapkan sistem hukum Islam. Sementara itu, di Kesultanan Malaka formalisasi dan legislasi hukum Islam cukup maju dan berkembang. Di kerajaan Islam ini pelaksanaan hukum Islam sudah berjalan stabil. Bahkan lengkap dengan syarat-syarat qadhi (hakim) yang akan memutuskan perkara di pengadilan juga telah ditetapkan. Disebutkan bahwa syarat seorang hakim harus seorang yang berilmu luas, adil, takwa, bijaksana dan bertanggung jawab. Ditetapkan pula untuk menjaga rasa keadilan dan kejujuran seorang hakim dilarang menerima hadiah. Kesultanan ini sudah dilengkapi dengan undang-undang yang dikenal dengan sebutan Kanun Malaka (Sunanto, 2007: 151).

Di Kalimantan Selatan praktik pelaksanaan hukum Islam dapat dilihat pada masa Kesultanan Banjar. Formalisasi dan legislasi hukum Islam melalui buku Sabil al-Muhtadin yang dilakukan seorang ulama, mufti sekaligus qadhi (hakim) Kesultanan Banjar yakni Syaikh Muhammad Arsyad Banjari. Kasus serupa diketahui dari legalisasi kitab Simbur Cahaya yang terdapat di Kesultanan Palembang yang memadukan hukum adat dengan hukum syariat (Ka'bah, 1999: 69). Untuk praktik hukum di Kesultanan Palembang ini memiliki kemiripan dengan hukum pepakem di Cirebon di Pulau Jawa, yakni dengan melakukan satu buku yang dijadikan pedoman kerajaan dalam Kitab Surya Alam (Hooker, 1983: 162-165).

Praktik formalisasi hukum Islam juga dilaksanakan di Pulau Jawa di berbagai kesultanan, misalnya pada kerajaan Islam pertama di Pulau Jawa, Kerajaan Demak, hukum Islam diberlakukan di samping hukum adat kebiasaan Jawa kuno. Hal ini karena Demak merupakan kerajaan yang berhasil menggantikan Kerajaan Majapahit yang bercorak Hindu Jawa. Masyarakatnya masih sangat kental dengan kebudayaan Jawa dan di antara mereka masih ada yang menganut agama Hindu. Maka, sebagai salah satu upaya dakwah Islam yang dilakukan adalah proses akulturasi budaya dan 
islamisasi dengan nilai-nilai Islam terhadap adat lama yang masih berkembang pada sebagian masyarakat. Akan tetapi, hukum Islam tetap diberlakukan dalam pelaksanaan peradilan. Hal ini tergambarkan dari peran peradilan kala itu yang menggunakan hukum Islam. Begitu juga dengan Kesultanan Cirebon, hukum Islam diberlakukan di samping hukum adat yang berlaku (Rusdi, 2011: 47-48). Namun hukum adat di Cirebon sudah disesuaikan dengan hukum Islam, sehingga Pepakem Cirebon yang dikenal sebagai hukum Jawa kuno tidak lain merupakan Undang-Undang Hukum Islam di Kesultanan Cirebon.

Dalam kasus Kesultanan Demak, meskipun sebagai kesultanan Islam pertama di Jawa, dalam praktik penerapan hukum Islam sudah ada jabatan qadhi yang dipercayakan kepada Sunan Kalijaga. De Graff dan Th. Pigeaud juga mengakui adanya jabatan tersebut dengan Sunan Kalijaga sebagai pejabatnya (Sunanto, 2007: 153). Meskipun belum ada keterangan lebih lanjut bagaimana susunan lembaga peradilan yang memberlakukan hukum Islam ini, namun cukup menjadi bukti yang kuat bahwa hukum Islam telah diformalisasikan dalam pemerintahan Demak, mengingat keberadaan jabatan qadhi menunjukkan adanya sistem peradilan Islam dalam memutuskan perkara di tengah kehidupan umat Islam.

Kesultanan Banten mengadopsi hukum Islam dalam menyelesaikan berbagai masalah hukum di antara umat Islam (Ka'bah, 1999:69). Pelaksanaan hukum Islam pada Kesultanan Banten berbeda dari kesultanan lainnya yang ada di Pulau Jawa. Tegasnya penerapan hukum Islam di Banten diduga karena pengaruh adat istiadat HinduBuddha di wilayah kerajaan ini tidak dominan, misalnya pada masa Sultan Hasanuddin sangat ketat dalam melaksanakan hukum Islam. Kesultanan ini dijalankan berdasar hukum Islam yang murni, sehingga peradilan yang diberlakukan pada pemerintahan ini murni dari hukum Islam. Pemberlakuan hukum pidana Islam merupakan bagian dari pelaksanaan syari'at Islam di Banten (Rusdi, 2011: 49). Meskipun masyarakat Banten bersifat heterogen atau multikultural (Wijono, 2017).

Di Kesultanan Banten pelaksanaan hukum Islam ditangani oleh hakim yang disebut qadhi (dalam bahasa Jawa disebut kali). Antara tahun 1651-1682 di bawah Sultan Ageng Tirtayasa diberlakukan hukum potong tangan bagi pencuri dengan kadar tertentu. Pada masa pemerintahannya ia mengangkat seorang ulama bernama Syaikh Yusuf al-Makassari sebagai mufti atau qadhi kerajaan (Sunanto, 2007: 142, 153). Pelaksanaan hukum Islam di Kesultanan Banten sepertinya meliputi semua aspek hukum perdata dan pidana Islam, sebab selain hukum potong tangan juga ada keterangan tentang hukuman bagi pengguna opium dan hukuman berat terhadap pelaku pelanggaran seksual (Azra, 1996: 69). Selain Banten formalisasi hukum Islam di Pulau Jawa juga dilaksanakan juga di beberapa kesultanan dan daerah seperti Demak, Jepara, Tuban, Gresik, Ampel dan kemudian Mataram (Ka'bah, 1999: 69).

Pada masa kerajaan Mataram Islam (16131645) di bawah kepemimpinan Sultan Agung, hukum Islam diberlakukan dalam sistem peradilan. Setiap kejahatan yang menjadi urusan peradilan diadili menurut hukum Islam. Sekalipun masih dalam upaya penyesuaian, namun sistem hukum Islam sudah diperkenalkan dan diformalisasi dalam sistem pemerintahan. Penghulu pada masa Sultan Agung mempunyai tugas tidak hanya sebagai imam, tetapi juga sebagai mufti atau penasihat hukum Islam, qadhi atau hakim, wali hakim dan amil zakat (Rusdi, 2011: 42). Sultan Agung juga yang mengubah peradilan pradata (Hindu) menjadi Peradilan Surambi atau Serambi. Disebut demikian karena peradilan ini bertempat di serambi Masjid Agung. Penghulu pada masa ini mempunyai tugas sebagai mufti, yaitu penasihat hukum dalam sidang-sidang pengadilan negeri (Maman, 2009: 102).

Dapat disimpulkan bahwa hukum Islam yang berlaku tidak hanya dalam tataran ibadah saja, seperti salat, zakat, puasa, haji, nikah dan waris, yang secara normatif tidak memerlukan bantuan penyelenggara negara untuk melaksanakannya dan dapat dijalankan atas dasar kesadaran individu umat Islam. Namun juga menyangkut hukum Islam yang berlaku secara formal yuridis, yakni hukum Islam yang mengatur hubungan sesama manusia dalam kehidupan masyarakat dan negara yang disebut dengan istilah muamalah dan uqubat, yakni hukum Islam yang memerlukan bantuan penyelenggaraan negara untuk pelaksanaan melalui upaya peradilan seperti pelanggaran kejahatan murni atau persengketaan hak milik dan 
semacamnya (Ali, 2011: 75). Artinya, pada masa ini formalisasi hukum Islam memiliki peranan sentral, karena menangani berbagai persoalan atau kasus-kasus yang terjadi di tengah-tengah masyarakat, baik menyangkut perkara perdata maupun pidana.

\section{Simpulan}

Dari penelusuran sumber-sumber sejarah dapat disimpulkan bahwa fase awal pengenalan hukumhukum Islam menjadi genealogi awal proses formalisasi hukum Islam di Nusantara. Pada fase ini hukum-hukum Islam sudah diperkenalkan kepada seluruh anggota keluarga dan komunitas masyarakat yang telah menerima Islam. Sejalan dengan proses islamisasi dan kulturisasi hukum Islam yang terus berkembang, hukum Islam pun menjadi bagian dari hukum tidak tertulis yang berkembang di Nusantara berkat akulturasi dan asimilasi hukum Islam dengan budaya lokal. Jika terjadi persengketaan biasanya dari pihak yang bersengketa itu mengangkat seorang muhakkam (pemutus perkara) secara tahkim dari kalangan ulama di antara mereka. Ini merupakan bentuk awal formalisasi hukum Islam secara sederhana yang pertama-tama diberlakukan di Nusantara yang biasanya dikenal dengan fase tahkim. Pada masa ini peran ulama dari Timur Tengah sangat berpengaruh dalam memperkenalkan hukum Islam dan kaderisasi tunas ulama Nusantara.

Fase berikutnya adalah setelah agama Islam mengalami perkembangan dan terjadi konversi penduduk di Nusantara ke dalam agama Islam. Pengaruh para ulama tetap memegang peranan strategis dalam mewarnai kehidupan masyarakat dan institusi politik di Nusantara. Pada masa ini bermunculan ulama Nusantara yang dipandang cukup berpengaruh dalam bidang hukum Islam, terbukti karya-karya buku mereka dijadikan sebagai pedoman pelaksanaan hukum Islam dalam pemerintahan. Pengaruh ulama ini juga terekam jelas pada saat pendirian kerajaan Islam pertama di Pulau Jawa yang diinisiasi oleh para ulama yang tergabung dalam Wali Songo. Pada saat Islam bekembang dan menjelma menjadi sebuah kekuatan politik inilah awal dari formalisasi hukum Islam di Nusantara. Kesultanan pada masa paling awal dalam melaksanakan formalisasi hukum Islam di Nusantara adalah Perlak pada abad IX hingga awal abad XIII dan Samudra Pasai abad XIII hingga awal abad XVI, hal ini dapat dibuktikan dengan keberadaan lembaga peradilan dan jabatan qadhi pada masa pemerintahan tersebut. Hukum-hukum Islam diterapkan dalam sistem pemerintahan dengan mejadikannya sebagai hukum negara menggantikan hukum adat di berbagai daerah Nusantara.

Sejak berdiri kekuatan politik Islam di Nusantara, ulama menjadi bagian penting dalam legitimasi dan pelaksanaan kekuasaan Islam di tengah masyarakat yang telah beralih memeluk agama Islam. Bahkan ulama dianggap ujung tombak dalam pelaksanaan hukum Islam dalam pemerintahan. Praktik formalisasi hukum Islam di masa kesultanan Islam dibuktikan dengan adanya undang-undang yang bercorak Islam dan lembaga peradilan Islam seperti Peradilan Serambi di Jawa, Mahkamah Syariyyah di Sumatra, Kerapatan Qadhi di Banjar dan Pontianak dan lain sebagainya. Setiap kesultanan mengangkat qadhi, mufti hingga syaikh al-Islam sebagai penopang utama dalam pelaksanaan formalisasi hukum Islam tersebut. Begitu juga bukti-bukti sejarah tentang penerapan hukum dan penanganan berbagai kasus baik di bidang perdata maupun pidana.

\section{Referensi}

Abdullah, R. (2015). Wali Songo: Gelora Dakwah dan Jihad di Tanah Jawa (1404-1482). Surakarta: Al Wafi Publishing.

Achmad, S. W. (2016). Sejarah Kerajaan-Kerajaan Besar di Nusantara. Yogyakarta: Araska.

Ali, M. D. (2011). Hukum Islam : Pengantar Ilmu Hukum dan Tata Hukum Islam di Indonesia. Jakarta: Rajawali Press.

Arif, M. (2011). Pengantar Kajian Sejarah. Bandung: Yrama Widya.

Arifin, A. H. (2005). Malikussaleh: Mutiara dari Pasai. PT. Madani Press.

Azra, A. (1994). Jaringan Ulama Timur Tengah dan Kepulauan Nusantara Abad XVII$X V I I I$. Bandung: Mizan.

Azra, A. (1999). Renaisans Islam Asia Tenggara. Bandung: Rosda Karya.

Batutah, I. (1992). Rihlah ibn Battutah alMusammah Tuhfah al Nazzar fi Gara'ib al- 
Amsar wa 'Aja'ib al-Asfar. Beirut: Darul Kutub al-'Ilmyyah.

Daliman, A. (2012). Islamisasi dan Perkembangan Kerajaan-Kerajaan Islam di Indonesia. Yogyakarta: Penerbit Ombak.

Departemen Agama RI (1985). Kenang-kenangan Seabad Peradilan Agama di Indonesia. Jakarta: Ade Cahya.

Hamka (1981). Sejarah Umat Islam. Jakarta: Bulan Bintang.

Harjono, A. (1995). Indonesia Kita: Pemikiran Berwawasan Iman-Islam. Jakarta: Gema Insani Press.

Hasymi, A. (Ed.), (1995). 50 Tahun Aceh Membangun. Banda Aceh: MUI Aceh.

Hidayat, A. (2012). "Non Zero Sum Game Formalisasi Syari'ah dalam Bingkai Konstitusionalisme." Jurnal Pandecta, 7 (1): 80-94.

Hikmatullah (2017). "Selayang Pandang Sejarah Penyusunan Kompilasi Hukum Islam di Indonesia." Jurnal Ajudikasi, 1 (2): 39-52.

Hill, A. H. (1960). "Hikayat Raja-Raja Pasai." Journal of Malaysian Branch and Royal Asiatic Society, Vol. 33 (2): 1-215.

Hill, A. H. (1963). "The Coming of Islam to Nort Sumatra." Journal of Southeast Asian History, Vol. 4 (1): 6-21.

Hooker, M. B. (1983). Islam in South-East Asia. Leiden: E.J.Brill.

Israeli, R. (1989). The Crescent in the East : Islam in Asia Minor. London: Curzon Press.

Ka'bah, R. (1999). Hukum Islam di Indonesia, Prespektif Muhammadiyah dan NU: Jakarta: Universitas Yasri.

Kartodirjo, S. (1993). Pendekatan Ilmu Sosial dalam Metodologi Sejarah. Jakarta: Gramedia Pustaka Utama.

Kenedi, H. J. (2017). "Penerapan Syariat Islam dalam Lintasan Sejarah dan Hukum Positif di Indonesia." Jurnal Nuansa, 10 (1): 74-84.

Lombard, D. (2014). Kerajaan Aceh Zaman Iskandar Muda (1607-1936). Jakarta: Gramedia Pustaka Utama.

Maman, K. (2009). "Ulama: Garda Terdepan Penegakan Syariah di Indonesia." Majalah Al-Wa'ie No.108.

Mukhlas, O. S. (2011). Perkembangan Peradilan Islam: dari Kahin di Jazirah Arab ke
Peradilan Agama di Indonesia. Bandung: Remaja Rosda Karya.

Nashir, H. (2013). Islam Syariat: Reproduksi Salafiyah Ideologis di Indonesia. Bandung: Penerbit Mizan.

Nuruddin, A. dan A. A. Tarigan (2006). Hukum Perdata Islam di Indonesia. Jakarta: Prenada Media.

Reids, A. (1993). The Making of an Islamic Political Discourse in South East Asia. Victoria: Monash University Press.

Rusdi, Kosim (2011). Sejarah Peradilan Agama di Indonesia. Cirebon: Penerbit Nurjati.

Saidah, S. (2013). "Aktualisasi Hukum Islam di Indonesia: Idealitas dan Realitas Hukum Pidana Islam." Jurnal Hukum Diktum, Vol. 11 (2): 147-158.

Sarkowi, S. (2015). "Pengaruh Islam terhadap Politik dan Pemerintahan Kesultanan Islam di Nusantara Abad IX-XIX". Prosiding Seminar Nasional Sejarah II. Palembang: FKIP Universitas Sriwijaya, 9 November 2015.

Sarkowi, S. dan Akip, M. (2019). "Kulturasi Ajaran Islam Melalui Sistem dan Lembaga Pendidikan Islam pada Masyarakat Masa Kesultanan di Nusantara”. SINDANG: Jurnal Pendidikan Sejarah Dan Kajian Sejarah, 1 (2): 36-53. https://doi.org/ https://doi.org/10.31540/sdg.v1i2.318

Sirajuddin M. (2016). "Sejarah Pergulatan Politik Hukum Islam di Indonesia”. Jurnal AlManahij, 10 (2): 281-294.

Sulasman, H. (2014). Metodologi Penelitian Sejarah: Teori, Metode, Contoh Aplikasi. Bandung: CV. Pustaka Setia.

Sunanto, M. (2007). Sejarah Peradaban Islam Indonesia. Jakarta: PT. Raja Grafindo Persada.

Surjaman, T. (ed.) (1991). Hukum Islam di Indonesia: Pemikiran dan Praktek. Bandung: Remaja Rosda karya.

Syamsuddin, D. (2015). Transformasi Hukum Islam di Indonesa." Jurnal al-Kadau, 2 (1): 114.

Usman, I. (2014). Konsep Pembinaan Umat dan Strategi Pelaksanaan Syariat Islam di Aceh.” Jurnal Media Syariah, 16 (1): 611-644.

Uwik, G. (2011). "Penerapan Syariah di Bumi Nusantara”. Majalah Al-Wa’ie No. 130. 
Wijono, R. S. (2017). “Di Bawah Bayang-Bayang Kota: Penataan Daerah di Provinsi Banten dari Zaman Kolonial sampai Zaman Reformasi." Jurnal Sejarah Citra Lekha, 2 (2), 126-142. https://doi.org/10.14710 /jscl.v2i2.16122

Yatim, B. (2016). Sejarah Peradaban Islam: Dirasah Islamiyah II. Jakarta: Rajawali Pers.

Yunus, N. R. (2015). "Penerapan Syariat Islam terhadap Peraturan Daerah dalam Sistem Hukum Nasional Indonesia." Hunafa: Jurnal Studia Islamika, 12 (2): 253-279.

Yusdani (2006). "Formalisasi Syariat Islam dan Hak Asasi Manusia di Indonesia." Jurnal Al Mawarid, Edisi XVI: 191-210. 